\title{
16. MINERALOGY AND DIAGENESIS OF SEDIMENTS AT SITE 597: PRELIMINARY RESULTS ${ }^{1}$
}

\author{
Miriam Kastner, Scripps Institution of Oceanography²
}

\begin{abstract}
Particles of red brown to yellow brown semiopaque oxides (RSO) dominate the insoluble residue fraction of the sediments at Site 597. Unlike the X-ray amorphous particles in the Bauer Deep sediments, these particles are composed of mainly goethite; the amount of X-ray amorphous ferric hydroxide and poorly crystalline ferromanganese oxyhydroxides is generally small relative to the amount of goethite.

A qualitative goethite crystallinity index was established. The variations observed in the crystallinity of goethite with increasing depth and changes in lithology suggest that aging and long-term exposure to seawater in a high water/sediment regime influence and increase the rate of recrystallization of the Fe-oxyhydroxides of the RSO particles.

The percentage of organic carbon is low in these sediments; it varies primarily between 0.2 and $0.4 \mathrm{wt} . \%$.

Phillipsite is present throughout the sediment column and is more concentrated in the youngest clay layer and in the oldest basal sediments.
\end{abstract}

\section{INTRODUCTION}

Site 597 is located at $18^{\circ} 48.38^{\prime} \mathrm{S}, 129^{\circ} 46.23^{\prime} \mathrm{W}$, at a water depth of $4166.5 \mathrm{~m}$. It is the oldest site cored during Leg 92; the crustal age is $28.6 \mathrm{Ma}$ (Rea, this volume). Of the $54.7 \mathrm{~m}$ cored, $52.7 \mathrm{~m}$ are sediments and $2.0 \mathrm{~m}$ are mixed sediment and basalt. Except for a thin ( 5-cm-thick) indurated siltstone $2.5 \mathrm{~m}$ above basement in Hole 597C, even the late Oligocene sediments in contact with the basalt are not indurated. The porosity in the calcareous section, however, decreases from 73 to $58 \%$, and the density and sonic velocities increase with depth (Site 597 chapter, this volume).

This site is below the carbonate compensation depth (CCD), as it has been for approximately 17 m.y. (Rea and Leinen, this volume). Hence, the uppermost $1.4 \mathrm{~m}$ are composed of a zeolitic clay that is rich in phillipsite and contains considerable amounts of $\mathrm{Fe}-\mathrm{Mn}$ oxyhydroxides. Since about $5 \mathrm{Ma}$, the CCD in this area has been situated at a depth of approximately $4100 \mathrm{~m}$ (Broecker and Broecker, 1974; Berger et al., 1976; Rea and Leinen, this volume), somewhat shallower than indicated by van Andel et al. (1975). The lysocline is about $600 \mathrm{~m}$ above the CCD (Rea and Leinen, this volume; Berger, pers. comm., 1985).

The rest of the sediment section (Unit II; Site 597 chapter, this volume) is a clay-bearing to clayey nannofossil ooze composed primarily of biogenic calcite and red brown to yellow brown semiopaque oxides (designated RSO by Leg 34 scientists; Quilty et al., 1976; Bass, 1976), some basaltic fragments, and only traces of terrigenous material.

Despite the thin sediment cover $(\sim 53 \mathrm{~m})$ and a heat flow (HF) value of $89 \mathrm{~mW} / \mathrm{m}^{2}$ (or $\sim 2 \mathrm{HF}$ units) that is somewhat elevated relative to the theoretically predicted

\footnotetext{
${ }^{1}$ Leinen, M., Rea, D. K., et al., Init. Repts. DSDP, 92: Washington (U.S. Govt. Printing Office)

Address: Geological Research Division (A-012), Scripps Institution of Oceanography, University of California at San Diego, La Jolla, CA 92093.
}

value of about $50 \mathrm{~mW} / \mathrm{m}^{2}$ (Sclater et al., 1971), the pore water chemistry profiles do not indicate convective flow through the sediment column. Except for a slight increase in $\mathrm{Ca}$ concentration with increasing depth, which may indicate $\mathrm{CaCO}_{3}$ dissolution, there is no evidence of recent reactions between the pore water and sediment (Gieskes et al., this volume).

Accordingly, the main objectives of this study were as follows:

1. To describe the RSO and the changes in its characteristics with increasing depth, and to compare the RSO with similar material from the Bauer Deep sediments;

2. To compare the RSO in the calcareous portion of the section with the Fe-Mn oxyhydroxides in the zeolitic clay, the youngest sediments at this site;

3. To compare the RSO in the oldest and youngest sediments recovered during Leg 92 (Sites 597 and 600, respectively); and

4. To identify and characterize diagenetic reactions in the various fractions of the sediment (including the carbonate, RSO, and basaltic fractions) that may indicate past convective flow at this site.

This chapter reports our findings to date at Site 597.

\section{METHODS}

Ninety-two samples of sediment and five samples of mixed sediment and basalt were analyzed by X-ray diffraction (XRD). Bulk sediment samples and the $<2 \mu \mathrm{m}$ and $>2 \mu \mathrm{m}$ fractions of the insoluble residue were studied.

$\mathrm{CaCO}_{3}$ content was determined by two methods: by $\mathrm{CaCO}_{3}$ dissolution in an acetic-acid Na-acetate buffer solution ( $\mathrm{pH} 4.7)$ and by $\mathrm{CO}_{2}$ coulometry (Table 1). The carbonate contents determined by the latter method are generally somewhat lower; the method is more precise. $\mathrm{CO}_{2}$ coulometer results are used routinely for chemical calculations.

The separation of the $<2 \mu \mathrm{m}$ fraction of the bulk sample and that of the $>2 \mu \mathrm{m}$ fraction of the insoluble residue were determined by the Stokes Law settling method. The results are presented in Table 1 and Figures 1 and 2 . At present the same samples are being analyzed by a TA-II Coulter Counter.

The insoluble residue fraction was (1) leached with ammonium oxalate and oxalic acid (Schwertmann, 1964) in order to remove amorphous ferric hydroxides and poorly crystalline ferromanganese oxyhydroxides. This leach does not attack goethite (Landa and Gast, 1973); and (2) the crystalline goethite was leached with a Na citrate-Na bicar- 
Table 1. $\mathrm{CaCO}_{3}$ and $<2 \mu \mathrm{m}$ fractions (wt. $\%$ ) of bulk sample and insoluble residue, Site 597.

\begin{tabular}{|c|}
\hline $\begin{array}{c}\text { Core-Section } \\
\text { (interval in cm) }\end{array}$ \\
\hline $1-1,7-9$ \\
\hline $1-1,59-61$ \\
\hline $1-1,108-110$ \\
\hline $1-1,137-139$ \\
\hline $1-1,145-147$ \\
\hline $1-2,9-11$ \\
\hline $1-2,60-62$ \\
\hline $1-2,125-126$ \\
\hline $1-2,129-130$ \\
\hline $1-3,16-18$ \\
\hline $1-3,35-36$ \\
\hline $1-3,37-38$ \\
\hline $1-3,106-108$ \\
\hline $1, \mathrm{CC}, 8-10$ \\
\hline $2-1,10-12$ \\
\hline $2-1,66-68$ \\
\hline $2-1,127-129$ \\
\hline $2-2,9-11$ \\
\hline $2-2,66-68$ \\
\hline $2-2,115-117$ \\
\hline $2-3,8-10$ \\
\hline $2-3,65-67$ \\
\hline $2-3,116-118$ \\
\hline $2-4,25-27$ \\
\hline $2-4,70-72$ \\
\hline $2-4,110-112$ \\
\hline $2-5,48-50$ \\
\hline $2-5,86-88$ \\
\hline $2-5,128-130$ \\
\hline $2-6,28-30$ \\
\hline $2-6,77-79$ \\
\hline $2-6,127-129$ \\
\hline $2-7,10-12$ \\
\hline $3-1,37-39$ \\
\hline $3-1,126-128$ \\
\hline $3-2,19-21$ \\
\hline $3-2,76-78$ \\
\hline $3-2,128-130$ \\
\hline $3-3,8-10$ \\
\hline $3-3,77-79$ \\
\hline $3-3,127-129$ \\
\hline $3-4,19-21$ \\
\hline $3-4,58-59$ \\
\hline $3-4,121-123$ \\
\hline $3 \cdot 5,19-21$ \\
\hline $3-5,79-81$ \\
\hline 3-5, $129-131$ \\
\hline $3-6,19-21$ \\
\hline 3.6, 49-51 \\
\hline $3-6,79-81$ \\
\hline $3-6,102-104$ \\
\hline $3-7,19-21$ \\
\hline $4-1,78-80$ \\
\hline $4-1,110-112$ \\
\hline $4-1,140-142$ \\
\hline $4-2,23-25$ \\
\hline $4-2,66-68$ \\
\hline $4-2,107-108$ \\
\hline $4,3,14-16$ \\
\hline $4-3,79-81$ \\
\hline $4-3,131-133$ \\
\hline $4-4,26-28$ \\
\hline $4-4,76-78$ \\
\hline $4-4,126-128$ \\
\hline $4-5,29-31$ \\
\hline $4-5,79-81$ \\
\hline $4-5,129-131$ \\
\hline $4-6,29-31$ \\
\hline $4-6,67-69$ \\
\hline $4-6,109-111$ \\
\hline $4, C C, 5-7$ \\
\hline $6-1,12-14$ \\
\hline $6-1,43-45$ \\
\hline $6-1,101-103$ \\
\hline $6-2,28-30$ \\
\hline $6-2,64-66$ \\
\hline $6-2,102-104$ \\
\hline $6-2,132-134$ \\
\hline $6-3,38-40$ \\
\hline $6-3,84-86$ \\
\hline $6-3,116-118$ \\
\hline $6-4,23-25$ \\
\hline $6-4,31-33$ \\
\hline $6-4,72-74$ \\
\hline $6-4,131-133$ \\
\hline $6-5,62-64$ \\
\hline 6-5, 93-95 \\
\hline $6-5,133-135$ \\
\hline $6-6,13-15$ \\
\hline $6-6,36-38$ \\
\hline $6-6,53-55$ \\
\hline $6, \mathrm{CC}$ \\
\hline $7, \mathrm{CC}$ \\
\hline $8-1,37-39$ \\
\hline $8-1,134-135$ \\
\hline $8, C C, 8-10$ \\
\hline $8, \mathrm{CC}, 11-12$ \\
\hline
\end{tabular}

a By dissolution in acetic acid- $\mathrm{Na}$ acetate buffer solution. By $\mathrm{CO}_{2}$ coulometry.

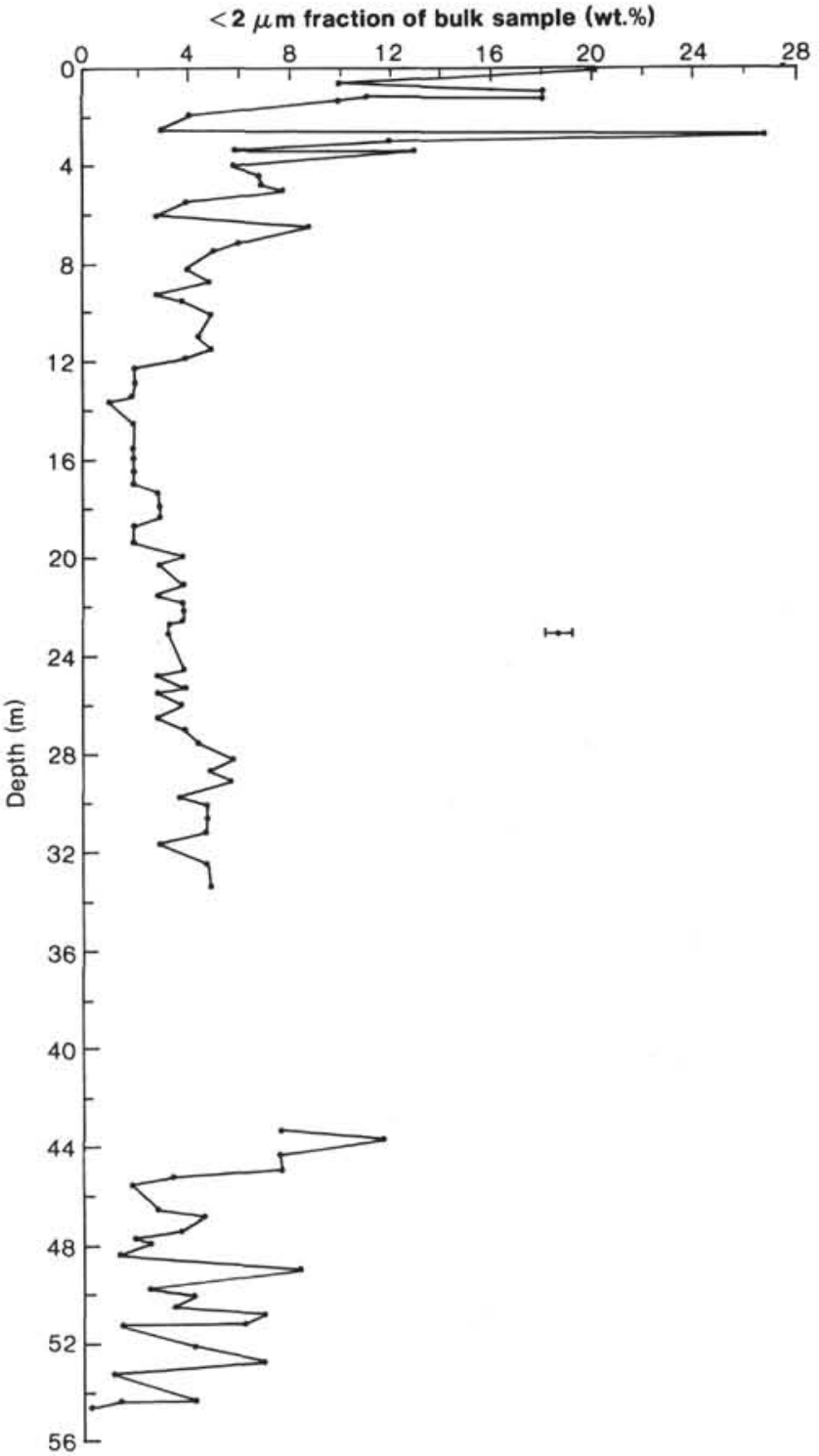

Figure 1. Amount (in wt. \%) of $<2 \mu \mathrm{m}$ fraction of bulk sample as a function of depth, Site 597.

bonate solution (Mehra and Jackson, 1960). The solution was analyzed for silica by molybdenum blue colorimetry to check for possible dissolution of silicates, especially of clay minerals. However, the amount of goethite in these samples is so high that one leach did not remove all the goethite. Indeed, either none or only traces of dissolved silica $(<1 \mathrm{ppm}, \pm 2 \%[<60 \mu \mathrm{M}])$ were observed, indicating minimal dissolution of silicates.

Controlled XRD analyses of the two insoluble residue fractions were used to establish a crystallinity index (Fig. 3). The results of analyzing the crystallinity of both size fractions of 60 samples are plotted in Figure 4.

Percent organic carbon was determined in 20 sediment samples by the $\mathrm{CO}_{2}$ coulometer.

\section{RESULTS AND DISCUSSION}

\section{RSO Particles and Grain Size Distribution}

The amount (in wt. \%) of the $<2 \mu \mathrm{m}$ fraction of bulk sample is higher in the uppermost 3 to $4 \mathrm{~m}$ and in Core 6 between about 43 and $52 \mathrm{~m}$ than in the middle, primarily calcareous zone (Fig. 1). The abundance of the 

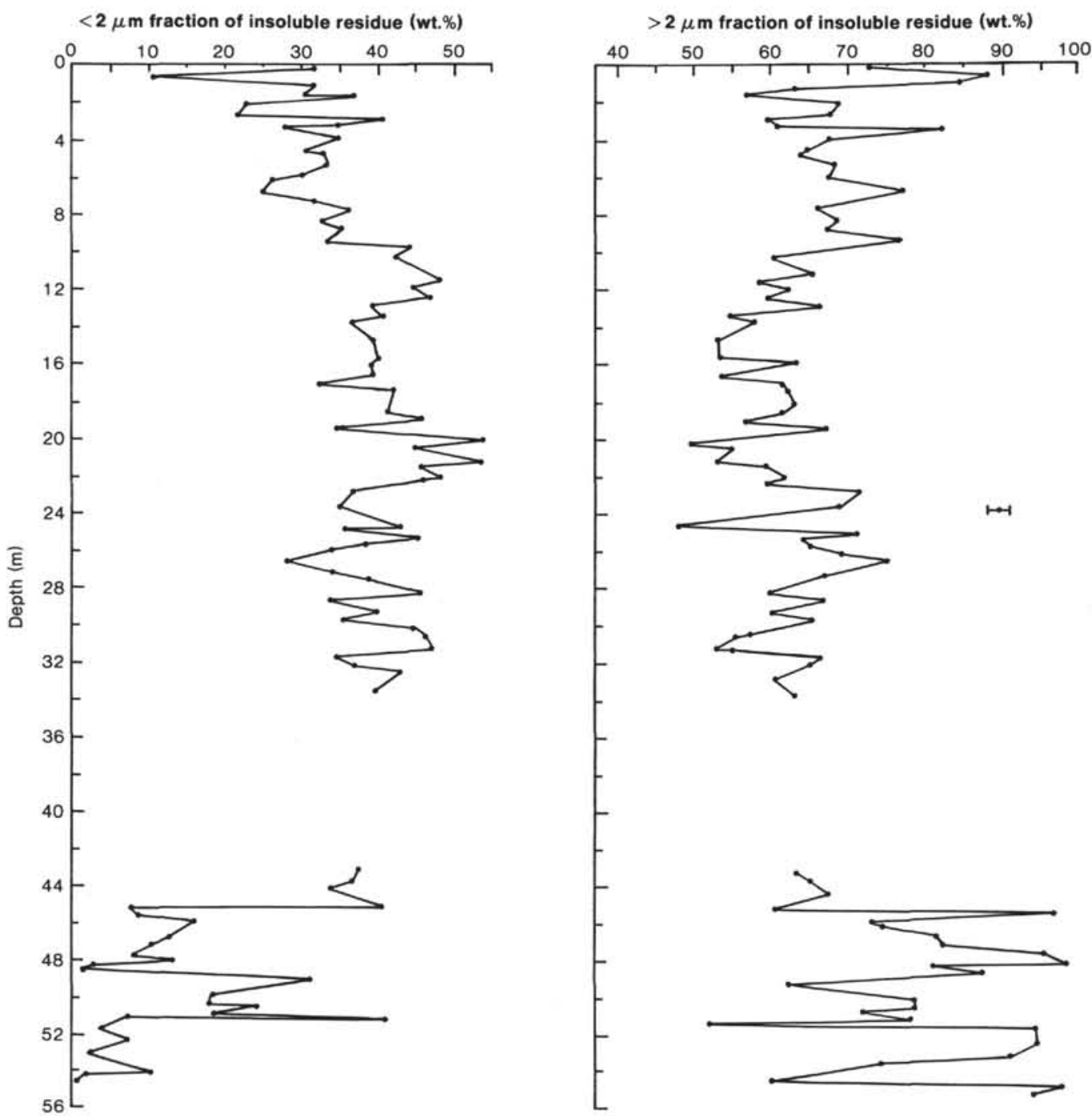

Figure 2. Amount (in wt. \%) of $<2 \mu \mathrm{m}$ and $>2 \mu \mathrm{m}$ fractions of insoluble residue as a function of depth, Site 597.

$<2 \mu \mathrm{m}$ fraction of the insoluble residue, which is dominated by Fe-Mn oxyhydroxides (RSO particles, Fig. 2), is, however, lowest at the same depths in the core.

Phillipsite occurs as euhedral to subhedral prisms up to $100 \mu \mathrm{m}$ long. It makes up a maximum of $10 \%$, but in most cases $<5 \%$, of the top $4 \mathrm{~m}$ of sediment. Thus, the RSO particles are responsible for most of the grain size distribution patterns shown in Figure 2.

The changes in the goethite crystallinity index occur at the same depths as the changes in the $>2 \mu \mathrm{m}$ distribution (Fig. 4); the average crystallinity index value is higher in the top few meters and in the Core 6 samples than in the central, high-carbonate zone. These trends suggest that the mean grain size of moderate to highly crystalline goethite is greater than the mean grain size of poorly crystalline goethite. Thus, the larger RSO particles occur not only in the deepest, oldest parts of the sediment column but also in the youngest sediments, which were deposited at the greatest distance from an active hydrothermal system. This grain size distribution suggests that the goethite crystallinity index may be used as a qualitative measure of the extent of the diagenesis of the originally X-ray amorphous RSO particles in the Bauer Deep sediments (e.g., Heath and Dymond, 1977).

The oldest, deepest sediments at Site 597 had more time for diagenesis. It is easier to explain the intense diagenesis of the oldest, deepest sediments ( $>25$ to 28.6 m.y. old; Knüttel, this volume) than it is to explain the diagenesis of the younger sediments; time is an extremely important diagenetic factor. The deepest sediments may also have been subjected to convective fluid flow when Site 597 was at or close to the Mendoza Rise (Mammerickx et al., 1980). The extremely slow sedimentation rates of 0.1 to $0.9 \mathrm{~m} / \mathrm{m}$.y. (Knüttel, this volume), and 15 to $17 \mathrm{~m} . \mathrm{y}$. of exposure to seawater close to and at the sediment/water interface (high water/rock system) could be responsible for the relatively high goethite crystallinity index in the youngest sediments.

Differences between the lithology, and thus the chemistry, of the zone rich in clay and the zone rich in calcareous nannofossils could also affect the rate of RSO diagenesis. 
(110) peak

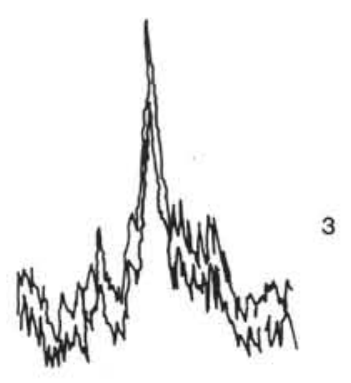

3


Figure 3. Qualitative goethite crystallinity index, Site 597. The superimposed X-ray traces represent the $<2 \mu \mathrm{m}$ and $>2 \mu \mathrm{m}$ fractions of the same sample. Units are relative crystallinity.

\section{Amorphous Ferric Hydroxide}

Unlike the RSO particles in the Bauer Deep sediments, which are composed of amorphous ferric hydroxide and poorly crystalline ferromanganese oxyhydroxides (Heath and Dymond, 1977), the RSO particles at Site 597 are composed mainly of goethite. The ratio of goethite to X-ray amorphous ferric hydroxide and poorly crystalline ferromanganese oxyhydroxides varies from 1.5 to 7.0. The systematics of the response of this ratio to sedimentological, oceanographic, and physical-chemical factors is still unknown. The ammonium oxalate and oxalic acid leach (Schwertmann, 1964), however, has no significant effect on the nature or intensity of the goethite peaks. According to Landa and Gast (1973), this absence of effect indicates that the amount of amorphous material is small.

\section{Other Diagenetic Reactions}

Phillipsite is abundant in the zeolitic clay layer, common in the Core 6 sediments, and present at irregular
Goethite crystallinity index

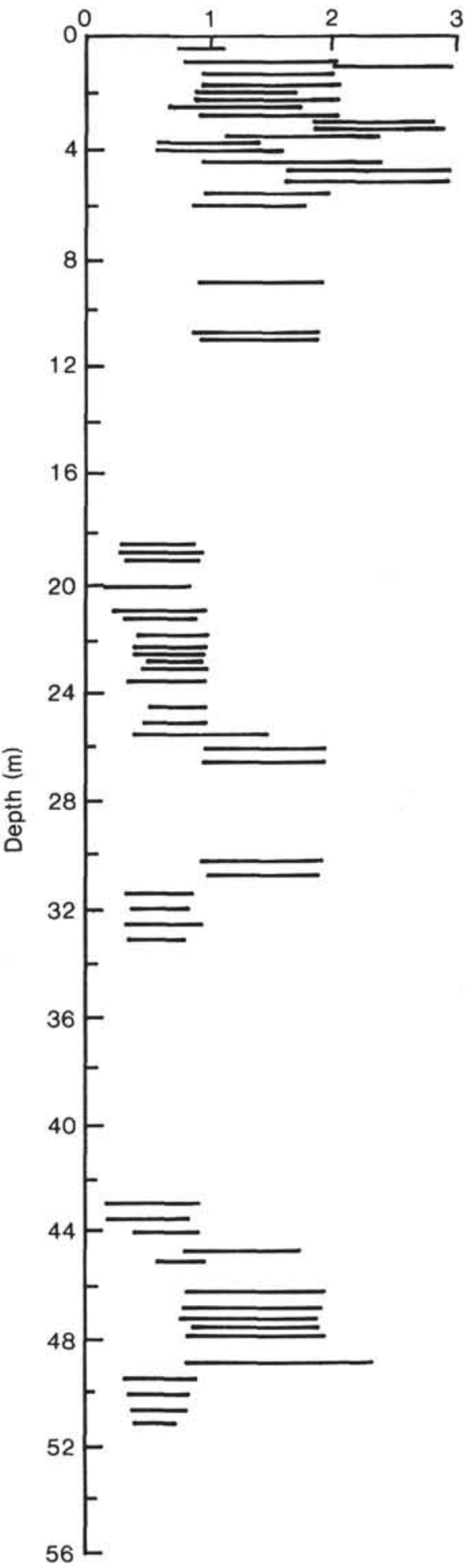

Figure 4. Variation of goethite crystallinity index as a function of depth, Site 597.

intervals throughout the section. It most likely formed from the alteration of volcanic glass. Diagenetic smectite is more abundant in the zeolitic clay zone and in the mixed sediment-basalt samples of Cores 7 and 8 than elsewhere in the section. In Cores 7 and 8, the abun- 
dance of the smectite increases with increasing numbers of basalt fragments. The smectite in the clay layer is poorly crystalline, and that in the basal sediments is moderately crystalline.

Calcite dissolution and overgrowth are common (Knüttel, this volume). The combined effects of convective fluid flow during the early history of this site and later subsidence below the lysocline and eventually below the CCD may have been responsible for the poor preservation of the biogenic calcite. The possibility of early convective fluid flow through the sediments is being investigated.

\section{Organic Carbon}

No trend in organic carbon concentration with increasing depth was observed. In the 20 samples analyzed, organic carbon concentration varied between approximately 0.05 and $<0.4 \mathrm{wt} . \%$. The data do not preclude the possibility of a small degree of organic carbon diagenesis and minor manganese remobilization.

\section{SUMMARY}

A preliminary study of the Hole 597 sediments indicates that the RSO particles are different and more complex in mineralogy and geochemistry than RSO from the Bauer Deep sediments. In the Hole 597 sediments, goethite is an abundant $\mathrm{Fe}$-hydroxide phase. The ratio of goethite to amorphous and/or poorly crystalline RSO particles varies between 1.5 and 7.0. A qualitative goethite crystallinity index was established. In the sediment at the top and bottom few meters of Hole 597, the goethite crystallinity index is higher than in the carbonaterich section at a burial depth between about 12 and $42 \mathrm{~m}$. Long-term ( $\approx 17 \mathrm{~m}$.y.) exposure to seawater and convective fluid flow may be responsible for the increased goethite crystallinity in the top and bottom sections of the sediment column, respectively.

\section{ACKNOWLEDGMENTS}

My thanks to Sam Savin for his review and suggestions on improving the manuscript, and to all participants of Leg 92 for a rewarding experience. This research was supported by NSF Grant OCE83-00692.

\section{REFERENCES}

Bass, M. N., 1976. Rare and unusual minerals and fossils (?) in sediments of Leg 34. In Yeats, R. S., Hart, S. R., et al., Init. Repts. $D S D P$, 34: Washington (U.S. Govt. Printing Office), 611-624.

Berger, W. H., Adelseck, C. G., Jr., and Mayer, L. A., 1976. Distribution of carbonate in surface sediments of the Pacific Ocean. $J$. Geophys. Res., 81:2617-2627.

Broecker, W. S., and Broecker, S., 1974. Carbonate dissolution on the western flank of the East Pacific Rise. In Hay, W. W. (Ed.), Studies in Paleoceanography. Soc. Econ. Paleontol. Mineral. Spec. Publ., 20:44-57.

Heath, G. R., and Dymond, J., 1977. Genesis and transformation of metalliferous sediment from the East Pacific Rise, Bauer Deep, and Central Basin, northwest Nazca Plate. Geol. Soc. Am. Bull., 88:723-733.

Landa, E. R., and Gast, R. G., 1973. Evaluation of crystallinity in hydrated ferric oxides. Clays Clay Min., 21:121-130.

Mammerickx, J., Herron, E., and Dorman, L., 1980. Evidence for two fossil spreading ridges in the southeast Pacific. Geol. Soc. Am. Bull., 91:263-271.

Mehra, O. P., and Jackson, M. L., 1960. Iron oxide removal from soils and clays by a dithionite-citrate system buffered with sodium bicarbonate. Clays Clay Min., 7:317-327.

Quilty, P. G., Sachs, H. M., Benson, W. E., Vallier, T. L., and Blechschmidt, G., 1976. Sedimentologic history, Leg 34. In Yeats, R. S., Hart, S. R., et al., Init. Repts. DSDP, 34: Washington (U.S. Govt. Printing Office), 779-794.

Schwertmann, U., 1964. Differenzierung der Eisenoxide des Bodens durch Photochemische Extraktion mit saurer Ammonium oxalat Lösung. Z. Pflazen. Düng. Bodenkunde, 105:194-202.

Sclater, J. G., Anderson, R. N., and Bell, M. L., 1971. Elevation of ridges and evolution of the central eastern Pacific. J. Geophys. Res., 76:7888-7915.

van Andel, T. H., Heath, G. R., and Moore, T. C., 1975. Cenozoic history and paleoceanography of the central equatorial Pacific Ocean. Geol. Soc. Am. Mem., 143.

Date of Initial Receipt: 29 October 1984

Date of Acceptance: 6 February 1985 